\title{
The Influence of Organization Social Capital on Strategic Performance in Role of Technological Uncertainly in Pharmaceutical Manufacturing Industries Iran
}

\author{
NimaKhodakarami ${ }^{1}$, Tarlan Razaghi ${ }^{1}$, Mohammad Rezvanifar ${ }^{2}$ and Mohammad Hajimolaali ${ }^{3 *}$ \\ ${ }^{1}$ Department of Management, Semnan Azad University, Iran \\ ${ }^{2}$ CEO and Managing Director of Tamin Pharmaceutical Investment Company, Iran \\ ${ }^{3}$ Department of Quality Assurance and Regulatory Affairs, Tamin Pharmaceutical Investment Company, Iran
}

Submission: March 29, 2018; Published: September 06, 2018

*Corresponding author: Mohammad Hajimolaali,Department of Quality Assurance and Regulatory Affairs, Tamin Pharmaceutical Investment Company,1966913481, Tehran, Iran, Email: Hajmolaali@gmail.com

\begin{abstract}
Background: In the past, social capital was not considered as a necessary quality for organizations but nowadays, due to fast environmental changes, growing need to information and education, essential needs for creativity and innovation, continuous progress, change to the design of a flat and flexible organizational structure, close connection between organization and customer networks, suppliers and competitors, social capital is considered as an organizational quality by leaders of organizations.
\end{abstract}

Objectives: Since the present world became a competitive world and the importance of social capital in the strategic performance of companies, this research has been carried out to investigate the effect of each component of social capital on strategic performance regarding moderator role of uncertainties of technology.

Method: The present research is descriptive-analytic study. The research community is the pharmaceutical companies in Tehran that selected randomly.

Results: Finally, research hypothesis was examined by using the structural equation model in the PLS software and it was determined that all dimensions of social capital (cognitive capital, relational capital and structural capital) have effect upon strategic performance however technology has not had a moderating role in this regard and failed to enhance the impact of the dimensions of social capital on strategic performance.

Keywords: Social capital;Cognitive capital;Strategic performance;Technological uncertainty; Industries; Social organization; Technology; Statistics; Literature; Demographic; Cognitive; Capital; Average

\section{Introduction}

In a knowledge-based economy, intangible assets of organizations are increasingly becoming a decisive factor in competitiveness. Such assets, such as skills and knowledge of employees, are viewed as the essence of competitive advantage [1]. Social capital is the set of norms in the social systems that promote the level of cooperation of the members of that society [2]. This capital points to the links and connections among the members of the network as a valuable resource, which creates norms and mutual trust, which serves the purposes of the members [3]. The experts consider social capital as aspects of social organization such as norms, social networks and mutual trust, which facilitates cooperation and cooperation of individuals to achieve common interests [4]. The idea of paying attention to social capital in organizations, as priests and prosecutors, is relatively new [5]. On the other hand, the discussion of strategic performance, which has always been considered by organizations, is affected by the social capital of the organization. In this process, the influence of interveners such as technology and its uncertainty can affect the severity and weakness of the impact of social capital on Influence strategic performance. Therefore, the present research seeks to investigate the effect of social capital on strategic performance by considering the moderating role of technology uncertainty.

\section{Methods}

There are various methods for collecting information that is often used in one or more methods for collecting statistics and information based on the type and desires of scientific research. In general, data collection methods are divided into two categories: library method and field method. In this research, both field 
and library methods have been used to collect information. The research literature was compiled by a library method and studied books, articles and searches on valid scientific websites. In this research, for analyzing the data obtained from the samples, both descriptive statistics and inferential statistics methods have been used. SPSS and PLS software were used to perform these analyzes [6]. In the descriptive section of the demographic information operations, individuals will be sampled using the SPSS software process. Also, tables and graphs containing mean, frequency, etc. will be used in this section. Structural Equation Modeling (SEM) has been used in the inferential part by using PLS software.

\section{Result and Discussion}

The purpose of this study was to examine the effect of social capital on strategic performance with respect to the moderating role of technological uncertainty. As previously mentioned, all dimensions of social capital (capital, structural, and structural) affect the strategic performance, but the technological uncertainty in these relations has no moderating role and failed to increase the impact of social capital dimensions on the strategic performance will be effective. Now, according to the results, the present research proposals are presented.Output results obtained from SMART PLC 2 software are presented in the following Table1.

Table 1: Reliability of the index of the research model.

\begin{tabular}{|c|c|c|}
\hline Dimensions & Cronbach's alpha & Combined Reliability (CR) \\
\hline Cognitive Capital & 0.83 & 0.88 \\
\hline Relational capital & 0.76 & 0.83 \\
\hline Structural capital & 0.85 & 0.75 \\
\hline $\begin{array}{c}\text { Strategic } \\
\text { performance }\end{array}$ & 0.74 & 0.83 \\
\hline
\end{tabular}

The increase of Cronbach's alpha and combined reliability of the main research structures of 0.7 , confirms the reliability of the model's proper index.The values for the Average(AVE) of each structure are shown in Table 2 . As you can see from this table, all AVE values are more than $0.4 \%$, which confirms the suitability of the model's consistent convergence.

Table 2: Average results of variance extracted variables for converging validity.

\begin{tabular}{|c|c|c|c|c|}
\hline Criteria & $\begin{array}{c}\text { Cognitive } \\
\text { Capital }\end{array}$ & $\begin{array}{c}\text { Relational } \\
\text { capital }\end{array}$ & $\begin{array}{c}\text { Structural } \\
\text { capital }\end{array}$ & $\begin{array}{c}\text { Strategic } \\
\text { performance }\end{array}$ \\
\hline AVE & 0.66 & 0.55 & 0.55 & 0.49 \\
\hline
\end{tabular}

\section{Discussion}

Given the relationship between social capital and strategic performance, active companies in the pharmaceutical industry will pay great attention to improving the strategic performance of social capital and its dimensions (capitalism, relational capital and structural capital); Use social capital indicators to evaluate strategic performance and, by forming professional groups and associations in organizations, increase social capital in organizations. About the relationship between capital and strategic performance, it is suggested that corporate values be promoted in the organizations and that staff be moved towards common goals. Also, all employees must be in the process of developing organizational norms and standards, and work towards increasing the number of employees with each other to improve the strategic performance of the organization. Regarding the relationship between relationship capital and strategic performance, it is suggested that in organizations, relationships should be structured in such a way that relationships based on cooperation and mutual trust are formed and cooperation is considered as an essential principle for employees. Also, by forming teams in the organization, the field of cooperation of the team of staff, the increase in criticism in the organization and the background of the commitment of more employees to the organization.

\section{Conclusion}

All dimensions of social capital (capital, cognitive, and structural) affect the strategic performance, but the technological uncertainty in these relationships has not a moderating role and could not be effective in increasing the impact of social capital dimensions on strategic performance. Companies active in the pharmaceutical industry will pay much attention to improving the strategic performance of social capital and its dimensions (capitalism, relational capital and structural capital), and to use social capital indicators to evaluate strategic performance, and by forming groups and associations Professional and specialized organizations increase social capital in organizations.

\section{Acknowledgment}

This research was supported by Tamin Pharmaceutical Investment Company.We thank our colleagues from Department of Strategic and Dr. Saleh Rahimi who provided insight and expertise that greatly assisted the research.

\section{References}

1. AugustoM, Coelho F (2009) Market orientation and new-to-theworld products: Exploring the moderating effects of innovativeness, competitive strength, and environmental forces. Industrial marketing management 38(1): 94-108.

2. BolinoMC, Turnley WH, Bloodgood JM (2002) Citizenship behavior and the creation of social capital in organizations. Academy of management review 27(4): 505-522.

3. Carey S, Lawson B, Krause DR (2011) Social capital configuration, legal bonds and performance in buyer-supplier relationships. Journal of Operations Management, 29(4): 277-288.

4. Cousins PD, Handfield RB, Lawson B, Petersen KJ (2006) Creating supply chain relational capital: the impact of formal and informal socialization processes. Journal of operations management24(6): 851863.

5. Glass AJ, Saggi (2002)International technology transfers and the technology gap.

6. Preacher KJ, Hayes AF (2004) SPSS and SAS procedures for estimating indirect effects in simple mediation models. Behavior research methods, instruments, \& computers 36(4): 717-731. 
(C) This work is licensed under Creative BY DOI: 10.19080/ASM.2018.01.555569

\section{Your next submission with Juniper Publishers} will reach you the below assets

- Quality Editorial service

- Swift Peer Review

- Reprints availability

- E-prints Service

- Manuscript Podcast for convenient understanding

- Global attainment for your research

- Manuscript accessibility in different formats

( Pdf, E-pub, Full Text, Audio)

- Unceasing customer service

Track the below URL for one-step submission https://juniperpublishers.com/online-submission.php 